\title{
Sustainable development Growth, Environment and Preservation in the Context of Globalization
}

In the sphere of neoliberalism and globalization, the proposal of Sustainable Development emerges to reconcile economic growth with respect for the environment guided by the interactive 'Economy/Sustainability' binomial and emerging as an alternative to the crisis of the emerging fossil/energy model with the First Industrial Revolution and fought in the period after World War II. In order to overcome dogmatic visions, sectarian extremisms and ideological cleavages, the Sustainable Development model favors local and national actions and public policy initiatives rather than transnational attempts in a way that does not compromise biodiversity. Sustainable Development, within its methodological scope, points out ways to reach the productive/technological progress of peripheral and semi peripheral countries

Keywords: Development; Sustainability; Globalization.

\section{Desenvolvimento sustentável Crescimento, meio ambiente $e$ preservação no contexto da globalização}

No âmbito do neoliberalismo e da globalização, emerge a proposta de Desenvolvimento Sustentável para conciliar crescimento econômico com respeito ao meio ambiente, orientada pelo binômio interativo 'Economia/Sustentabilidade' e emergindo como alternativa à crise do modelo fóssil/energético emergente. Primeira Revolução Industrial e lutou no período após a Segunda Guerra Mundial. Para superar visões dogmáticas, extremismos sectários e clivagens ideológicas, o modelo de Desenvolvimento Sustentável favorece ações locais e nacionais e iniciativas de políticas públicas, em vez de tentativas transnacionais de uma maneira que não comprometa a biodiversidade. O Desenvolvimento Sustentável, dentro de seu escopo metodológico, aponta maneiras de alcançar o progresso produtivo/tecnológico dos países periféricos e semi-periféricos.

Palavras-chave: Desenvolvimento; Sustentabilidade; Globalização.

Topic: Desenvolvimento, Sustentabilidade e Meio Ambiente

Reviewed anonymously in the process of blind peer.
Received: 02/10/2019

Approved: 26/11/2019

Manoel Gonçalves Rodrigues (it)

Universidade Federal do Rio de Janeiro, Brasil

http://lattes.cnpq.br/5940113046592928

http://orcid.org/0000-0002-1014-5604

manoel.grodrigues@gmail.com

Fernando José Pereira da Costa

Universidade Federal do Rio de Janeiro, Brasil

http://lattes.cnpq.br/0908286687921354

fjpcosta@sapo.pt

Referencing this:

RODRIGUES, M. G.; COSTA, F. J. P.. Sustainable development Growth, Environment and Preservation in the Context of Globalization. Revista Ibero Americana de Ciências Ambientais, v.10, n.6, p.251-259, 2019. DOI: http://doi.org/10.6008/CBPC2179-6858.2019.006.0022 


\section{INTRODUCTION}

As reported by Gallo et al. (2012), the first oil shock in 1973 and the ensuing inflationary wave (aggravated by the 1979 oil shock) would mark the transition phase between the Welfare State model. and neoliberalism. That model favors the fiscal and monetary balance of countries, in order to reduce social and labor and welfare protection systems, so as to give the market the possibility of assuming social needs to the detriment of the state area insurance, private health plans, private pension, etc. The consequence of the widespread implementation of the policies, especially at developing countries, has had adverse consequences for their populations, but has also had adverse impacts at the level of organic-central countries.

For Oliveira et al. (2009), the Sustainable Development model emerges as a well-finished synthesis of the critique of the fossil/energy model inherited from the First Industrial Revolution and the productivist development model adopted by the capitalist economy and industrial society after World War II. This model was based on the intensive use of natural resources (especially energy resources), presenting high degrees of environmental degradation and high levels of social inequality, despite the good results in terms of profit generation.

The energetic model in the use of natural resources has led to a huge degradation of the environment, with high production and productivity rates not reverting to the majority of the population, especially in the developing countries. In turn, the concept of sustainability encompasses several dimensions: social, economic, ecological, spatial and cultural; and while Sustainable Development presupposes a profound transformation in society (overcoming ideological differences, antagonisms between countries and cleavages between social groups), seeking an alternative model of development that considers the finite character of resources.

\section{METHODS}

\section{Sustainable Development}

According to what Silva et al. (2017) and Kates et al. (2001) put it, Sustainable Development is indispensable for any and every economy, since through sustainability it is possible to ensure the continuation of economic growth without this leading to This is due to resource scarcity, ensuring growth without over-eroding the natural resource base to meet current needs without compromising the needs of future generations. Thus, the process of economic growth/development does not compromise local biodiversity. In fact, according to Oliveira (2010), the concept of sustainability is related to the rational use of natural resources and the avoidance of waste, the development/use of new technologies, the search for more efficient substitutes for perishable materials, better use of inputs, the use of new (notably renewable) energy sources and the use of new waste treatment procedures.

On the other hand, for Silva et al. (2017), Santos (2008) and Filho (2001), the concept of Sustainable Development is structurally integrative of environmental policies and development strategies, in an 
interaction in which the economic variable is a constant presence, as there are a number of factors (the implementation of new laws, complaints and pressures from consumers or the conscience of entrepreneurs themselves) that imply either a new stance or following new rules, especially with regard to industrial activities, with a clear impact on production costs. The adoption of the sustainable development model at the economic system level implies that it is possible to be guided by the binomial 'Development/Preservation'. On the other hand, both economic and population growth at current levels of consumption tend to degrade/destroy the environment and natural resources. This is very likely to lead to a stranglehold on development possibilities to undermine the quality of life of the population.

Carvalho et al. (2009) point out that Sustainable Development, in its classic definition (taken from the Brundtland report), shows itself as a response to problems related to environmental degradation, accelerated depletion of the natural resource base and social inequalities generated by energyaggressive/environment-friendly model inherited from the First Industrial Revolution. The concept of Sustainable Development proposes the commitment 'Ecology/Economy' in order to reconcile technological intervention with the planet's ecosystem capacity. Indeed, the implementation of Sustainable Development was initially based on two fundamental dimensions: economic development and environmental protection.

In fact, the Sustainable Development proposal was the conciliatory line 'Environment/Development', initially based on two fundamental dimensions: economic development and environmental protection. The third aspect to be further integrated was the social one. Thus, the current implementation of Sustainable Development is based on three fundamental dimensions, namely: economic development, social cohesion and environmental protection, in addition to the institutional aspect, which draws attention to issues of governance of the institutions and legislative systems (flexibility, transparency and democracy), interest groups (trade unions and business associations) and civil society as a whole.

From Souza (s/data) and Bruseke (1996) it is ensured that the process of economic development occurs in various ways (essentially private activity, indirect intervention by regulation and state intervention). However, the Sustainable Development model implies considering growth/development while preserving the natural resource base and not degrading the environment. Therefore, Sustainable Development would have a major set of concerns, namely: environmental preservation; the solidification of social structures; the active participation of civil society; the preservation of natural resources and the environment in general; the elaboration of a social system guaranteeing employment, social security and respect for other cultures; the formulation/implementation of public policies related to infrastructure; etc. Sustainable Development meets the needs of the present without risking future generations from meeting their needs. The concept of Sustainable Development brings a new philosophy, based on economic efficiency, ecological prudence and social justice. In order to meet the objectives of Sustainable Development, some measures are listed, namely: limitation of population growth; long term power guarantee; preservation of biodiversity and ecosystems; decreased energy consumption; development of technologies that allow the use of renewable energy sources; increased industrial production in non-industrialized countries on the basis of ecologically adapted 
technologies; control of wild urbanization and integration between countryside and smaller cities; satisfaction of basic needs.

It will be Candido (2010) to note that the current growth model (oil/energy) has generated economic, social and environmental imbalances. Therefore, the Sustainable Development proposal advances as an alternative model in the 'Development/Environment' relationship, which seeks to reconcile economic growth/development with environmental preservation and social goals (addressing poverty). Indeed, the concept of sustainable development emerges to address the ecological crisis and to address the need to harmonize the treatment of the environmental issue with the socioeconomic approach so as to maximize the production of ecosystems to meet present human needs and future.

In this way, the interaction 'Development/Quality of Life' becomes compatible with sustainability and the pursuit of future development. The concept of Sustainable Development has had the merit of overcoming the quarrel between the organic-central countries, holders of industrialized economies and that have advanced throughout history harming the environment and the peripheral/semi-peripheral countries, facing huge demands of economic and social nature. Social. On the other hand, the concern with Sustainable Development implies the possibility of guaranteeing the occurrence of socio-political changes without compromising the ecological/social systems.

For Candido (2010), the concept of Sustainable Development does not imply a stationary stage, based on the idea of sustainability, which implies an adequate contribution to the maintenance of growth and capital, as well as the efficient use of natural resources. Sustainability has different degrees according to the maintenance of four types of capital, namely: man-made capital, which is the capital that is affectionate to industry and which is the most measurable; natural capital, which refers to goods supplied by the environment; human capital, considered as fundamental for the development strategy and social capital, which comprises the institutional/cultural bases for the functioning of society. Therefore, ecological sustainability means respect for the integrity of the ecosystem. On the other hand, it is important to note that the social side is extremely important, since its development refers to a number of aspects (equity, social mobility, social cohesion, participation, empowerment, cultural diversity and development institutional). However, the concept of sustainable development can be seen as a utopia for the 21st century, through which the need to seek a new scientific paradigm capable of replacing industrialism is postulated.

Indeed, as Candido (2010) warns, the historical world reality shows that the organic-central countries needed approximately half of the planet's resources to achieve prosperity. The organic-central countries profoundly altered their environment, were also responsible for the devastation of the natural resources of their then colonies and had to intervene deeply in the environment through the increasing consumption of natural resources. In fact, the threshold of an environmental collapse has been reached, due to the historical depletion of natural resources resulting from a predatory model of development. Indeed, peripheral/semiperipheral or developing countries have the right to grow economically and to rise to more favorable positions in the context of the world economy, although without repeating the predatory model followed by the organic-central countries, so as to not compromise your natural resource base. Therefore, the 
Sustainable Development proposal points to the submission of human civilizations to the precepts of ecological prudence, so as to make the non-predatory and rational use of nature.

\section{RESULTS AND DISCUSSION}

\section{Globalization and Sustainable Development}

Globalization must be understood as the current stage of world capitalism, characterized by the liberalization of spaces and markets especially financial markets and, therefore, may also be called neoliberal globalization, as it is closely associated with the movement of (re) or (neo) liberalization of the economy as of the seventies of the last century, which coincided with the Welfare State debacle, established the primacy of the economy (of markets) over politics and social and intensified the aggressive (already longstanding) about the environment.

The question is whether the proposal for sustainable development makes sense and whether it is feasible to apply this development model in the midst of globalization. Firstly, it is necessary to establish parameters/limits (economic, political, social, ethical, among others) in the relation 'Globalization/Environment'. Then, it is necessary, in the process of neoliberal globalization (in the order of the process), to define parameters for the formulation and implementation of development projects for the different countries of the planet, especially for those that make up the world's developing.

In the context of globalization, aggressions to the environment are accentuated, due to the strong liberalization of predatory economic activities, the intense deregulation of economic and productive life and the absence of a regulatory framework in environmental terms. On the other hand, global business, implemented by transnational corporations, creates strong pressures on the environment, especially in developing countries, making it difficult to implement alternative policies guided by the two-way 'Development/Environment' interaction.

According to Assis (2003), the issue of Sustainable Development becomes more prominent with the intensification of the globalization process, with the process of environmental disaggregation expanding in the poorer regions of the developing countries, in which populations, due to survival, are driven to use natural resources in a predatory manner. However, the globalization process is characterized by a search for homogenization of consumption patterns, even though capitalist decisions are made based on local characteristics, leaving room for the elaboration/implementation of local (or national/local) development policies.

However, the traditional pattern of development has always been linked to the issue of growth and mimicry of consumption patterns. From the crisis of the 1980s, there has been the strengthening of the ecological issue and the confirmation that the dominant technological pattern in the in the organic-central countries it was not amenable to worldwide generalization, which would lead to the reflection that a process of economic growth that was qualitatively distinct from the organic-central world would be necessary. This would imply that the microeconomic rationality of private agents would be subjected to a macrosocial 
rationality that would guarantee social justice and the conservation of natural resources in order to ensure satisfactory levels of well-being in current and future societies.

According to what Assis (2003) points out, we are looking for a development model that is based on economic growth that would allow the maintenance or increase over time of the set of economic, ecological and without which economic development would not be sustainable. In other words, it is necessary to consider the interdependence between economic growth, social justice and conservation of natural resources, which reflects the 'Economy/Nature' interaction, having as its central axis the improvement of human quality of life within the limits of carrying capacity. ecosystems, which shapes the proposal of Sustainable Development.

For the implementation of Sustainable Development, it is necessary to objectify the harmony/rationality 'Man/Nature', and development actions should be guided by respect for local development, even in a globalizing context. On the other hand, rising consumption patterns can lead more to waste than to higher levels of quality of life. Neoliberal globalization, the current stage of the world economy, justifies/enables the primacy of efficiency, which materializes through the clear prevalence of possessive/consumerist individualism over solidarity. Economic liberalization implies the absence of social, political and economic protection. In the case of developing countries, this implies the impossibility of any form of development coordination, linking the national economy to factors external to it.

As pointed out by Assis (2003), the subordinate insertion of developing countries in the context of the world economy, in the context of globalization, and their external subordinate attachment implies capital flight. This obliges them to maintain very high domestic interest rates (attracting foreign capital), which discourages productive investments and proves counterproductive in promoting economic growth, leading to a reduction in aggregate demand for wage and capital goods. generating recession/unemployment. The break with this highly perverse process involves the pursuit of productivity gains that would drive the increase in exports from these countries in order to balance the balance of payments. However, this measure is innocuous in view of the low international competitiveness of peripheral/semi-peripheral countries, which is manifested by the great difficulty that these countries have in attracting foreign direct investment in a globalized economy. Globalization intensifies competition between countries and regions, leading to the fragmentation of national states.

Thus, due to what is pointed out by Assis (2003), if the global one bets on homogenization, capitalist decisions are local, with knowledge assuming the position of main locational variant, which makes room for initiatives related to Sustainable Development via investments. Research and Development (R\&D), in order to retain positions or conquer new markets. According to Assis (2003), the locational economic conditions do not materialize due to global designs, since their generation occurs outside the market scope, but rather due to social determinants. Therefore, the goals of Sustainable Development are achieved through local actions/initiatives, which implies the development of the skills of the inhabitants in order to target local interests. However, this will only be possible through public investments in education, science and technology. 
However, with globalization, the action of transnational corporations and the deterritorialization of decisions have weakened the power of national states, which is extremely felt in the case of developing countries, whose access to technology is hampered by international relations affecting the world. world economic order that are favorable to the organic-central countries. In this way, the State's capacity as a public policy maker/promoter is weakened, making it in many cases the position of passive bystander of the whole process, which is practically dramatic in the case of the developing countries, which would require a strong, dynamic and strategically positioned state to meet development needs and to promote a world economy upgrade.

Indeed, as highlighted by Assis (2003), this is the great difficulty that neoliberal globalization poses to the implementation of Sustainable Development. The normal path of globalization coincides with the natural / historical path of capitalist accumulation (the increasing increase of inequality and social exclusion). The fragmentation of national power together with the decision-making power of investment linked to the interests of transnational corporations perpetuates mechanisms of social exclusion and makes it impossible to strengthen regional markets, which favor economic investments linked to local sociocultural needs and the availability of natural resources. different regions. The absence of coordinated action by developing countries leads to an uncoordinated process of capturing transnational financial resources, with the strengthening of market mechanisms at the expense of political power and sociocultural values. This intensifies resource/investment competition and articulation with transnational corporations. On the other hand, a national/local project (regional and intrabloc) favors investments in infrastructure, training and production, based on political power and sociocultural values.

Therefore, the adoption and implementation of a development program $/$ model based on the Sustainable Development proposal favors/stimulates productive investments of locational nature inserted in a distinct national (and in many cases opposite) dynamics to the neoliberal global rationale affects the markets. and to transnational corporations. Thus, the Sustainable Development project is consistent with the indigenous/self-sustained development initiatives. In fact, there is no compatibility between the realization of locational economic conditions and global interests, since they originate outside the market, but rather because of social determinants. Therefore, the goals of Sustainable Development are achieved from local actions/initiatives.

Souza (s/data) notes that the conception of Sustainable Development proposes the balance between environmental protection and economic development, in a context marked by the hegemony of neoliberalism and globalization. Maintaining the structures of the capitalist mode of production has what is meant by economic growth, which can be understood as the optimal development of production, occurring mainly from the introduction of technological and consumption innovations, which, through application of profit as capital for reproduction, a number of key factors (production, profit and investments in future production).

However, economic growth presents negative externalities to the environment (absorption of waste, waste and waste, depletion or misuse of energy sources, infrastructure problems, unemployment and other 
social problems, among others.). However, taking these problems as the object of analysis, the concept of economic development is constructed, which considers the improvement and guarantee of better and healthier living standards for the population (social welfare), coordinated with a balanced income distribution, possession of material goods and increased consumption capacity, so as to revert to the wellbeing of the population (maintenance of physical and mental health of individuals, access to healthy food, quality of water consumed, availability to leisure, health index of the work environment, etc.).

Bonelli et al. (2012) point out that the 21st century, in terms of economic development strategy, may correspond to a period of shared prosperity, characterized by a decrease in the income gap between the organic-central and developing countries, not because of the decrease in the income of the former, but because of the rapid advance on the part of the income of the latter. This must be taken in trend terms, with rising incomes underpinning political and social stability, as well as building more open societies, as well as diminishing conflicts.

Then, in this field, it is essential to promote the technological leap (advanced technologies) by the developing countries countries in the most diverse fields (namely: power generation, medicine, transportation, construction, sanitation, information technology and others), as has happened in the organiccentral world. Here's a key hypothesis: Prosperity can be widespread in every corner of the world, and if the organic-central countries today are so, they have adopted advanced technologies, for example in the field of power generation, medicine, transportation, construction, sanitation, information technology and others. These advanced technologies can also be adopted in the currently poor countries.

\section{CONCLUSIONS}

The Sustainable Development concept advocates that zero growth can be as harmful/harmful to the environment as uncontrolled economic growth and introduces the idea that quality of life, social justice and the fight against poverty are fundamental to ensure sustainability in environmental, economic and social terms. Sustainable Development takes equity, security and the environment as key elements, which will require an integrated/interactive approach that makes it possible to understand the complex/interactive 'Society/Nature' relationship. In fact, environmental degradation or depletion of natural resources affects people, societies and countries in different ways, creating/reinforcing new forms of social and economic discrimination. Indeed, in many developing countries, with high unemployment rates, there are significant facilities for accommodating and hosting polluting industries.

Finally, the concept of sustainable development does not fall into extremism and does not anathematize economic growth, but rather fits it within the scope of sustainability and environmental preservation, as well as the limits of the natural resource base and the intergenerational commitment to the planet. Sustainable Development considers the configuration assumed by world capitalism and rescues the question of development for developing countries, in order to present concrete proposals and viable paths for growth and development for these countries, relating alternatives with respect environment in the context of the 'Economy and Sustainability' interaction. Therefore, Sustainable Development points the way 
for a society that respects life and the environment without neglecting the growth/development needs of peripheral/semi-peripheral countries, which need to strongly reconcile their needs for improved living standards with respect to the environment.

\section{REFERENCES}

ASSIS, R. L.. Globalização, Desenvolvimento Sustentável e Ação Local: O Caso da Agricultura Orgânica. Cadernos de Ciência \& Tecnologia, Brasília, v.20, n.1, p.79-96, 2003.

BONELLI, V. V.; LAZZARESCHI, N.. Globalização, Desenvolvimento Sustentável, e Geração de Emprego. Revista Pensamento \& Realidade, v.27, n.4, 2012.

BRÜSEKE, F. J.. Desestruturação e Desenvolvimento. In: FERREIRA, L. C.; VIOLA, E.. Incertezas de Sustentabilidade na Globalização. Campinas: EDUNICAMP, 1996.

CANDIDO, M. C. A.. Desenvolvimento Sustentável e Pobreza no Contexto de Globalização: O Caso de Moçambique. Dissertação (Mestrado em Ciência Política e Relações Internacionais) - Universidade Nova de Lisboa, Lisboa, 2010.

CARVALHO, N.; LISBOA, M.; ROQUE, A.. Novas Formas de Economia e de Desenvolvimento Sustentável: As Dinâmicas dos Actores Sociais. In: CONGRESSO DE DESENVOLVIMENTO REGIONAL DE CABO VERDE, 1; CONGRESSO DA ASSOCIAÇÃO PORTUGUESA DE DESENVOLVIMENTO REGIONAL, 15; CONGRESSO LUSÓFONO DE CIÊNCIA REGIONAL, 2; CONGRESSO DE GESTÃO E CONSERVAÇÃO DA NATUREZA, 3. Anais. Praia, 2009. p.500-531.

FILHO, G. M.. As teorias clássicas do desenvolvimento econômico examinadas sob a ótica ecológica. O mito do desenvolvimento sustentável. Meio ambiente e custos sociais no moderno sistema produtor de mercadorias. Florianópolis. Florianópolis: EDUFSC, 2001.
GALLO, E.; SETTI, A. F. F.; MACHADO, J. M. H.; BUSS, D. F.; FRANCO NETTO, F. A.; MAGALHÃES, D. P.. Saúde e Economia Verde: Desafios para o Desenvolvimento sustentável e erradicação da pobreza. Ciência \& Saúde Coletiva, v.17, n.6, p.1457-1468, 2012.

KATES, B. R.; PARRIS, T. M.; LEISEROWITZ, A.. What is sustainable development?. Goals, indicators, values, and practica. Environment, v.47, p.8-21, 2001.

OLIVEIRA, A. M.; MAIA, L. S. C.; FREIRE JÚNIOR, L. G.. Globalização, Sustentabilidade e Políticas Públicas de Geração de Emprego e Renda. In: JORNADA INTERNACIONAL DE POLÍTICAS PÚBLICAS, 4. Anais. São Luís, 2009.

OLIVEIRA, D. L.. Economia e sustentabilidade. Gestão \& Tecnologia, v.3, p.14-21, 2010.

SANTOS, J. N. T.. A Leitura como instrumento de responsabilidade social: projeto energia da leitura na Eletronorte. Monografia (Graduação em Biblioteconomia) Universidade Federal do Pará, Belém, 2008.

SILVA, E. L.; SILVA, M. F.; NUNES, E. R. C.; SILVA, J. M.; OLIVEIRA, S. S.. O Desenvolvimento Sustentável na Economia Brasileira. Empreendedorismo, Gestão e Negócios, v.6, n.6, p.55-72, 2017.

SOUZA, S. C. F.. Globalização, Meio Ambiente e Desenvolvimento Sustentável. Nova York: Mimeo, (s/data). 